\title{
HUBUNGAN ANTARA MOTIVASI BELAJAR DENGAN PRESTASI BELAJAR MATEMATIKA SMP KELAS VIII
}

\author{
Pujilestari \\ Dosen FPMIPA IKIP Mataram, JI. Pemuda No. 59 A, Mataram, NTB \\ Email : pujilestari966@gmail.com
}

\begin{abstract}
ABSTRAK
Penelitian ini bertujuan untuk mengetahui hubungan antara motivasi belajar dengan prestasi belajar matematika pada siswa kelas VIII SMPN 1 Batukliang Utara. Jenis penelitian ini adalah eksperimen. Penelitian eksperimen adalah metode penelitian yang digunakan untuk mencari pengaruh perlakuan tertentu terhadap yang lain dalam kondisi yang terkendalikan. Pendekatan yang digunakan dalam penelitian ini adalah pendekatan kualitatif dan kuantitatif. Rancangan penelitiannya adalah data motivasi belajar siswa diperoleh dengan angket motivasi sedangkan data prestasi belajar siswa diperoleh dari hasil test. Desain yang digunakan dalam penelitian ini adalah Time Series Design. Populasi adalah siswa kelas VIII SMPN 1 Batukliang Utara yang berjumlah 105 orang, sedangkan sampel berjumlah 27 orang siswa kelas VIII A. Teknik pengumpulan data yang digunakan dalam penelitian ini adalah metode angket dan metode tes. Instrumen yang digunakan dalam penelitian ini adalah lembar angket dan lembar tes. Berdasarkan hasil penelitian ini menunjukkan bahwa terdapat hubungan yang positif dan signifikan antara Motivasi belajar siswa (X) terhadap Prestasi belajar matematika (Y). Dari hasil analisis data menunjukkan Korelasi antara motivasi belajar dengan prestasi belajar matematika yang diperoleh nilai $r$ tabel dan $r$ hitung untuk taraf kesalahan 5\% dengan $n=27$ diperoleh $r$ tabel $=0,381$ dan $r$ hitung=0,388. Karena harga $r_{\text {hitung }}>r_{\text {tabel }} \quad(0,388>0,381)$ maka dapat disimpulkan terdapat hubungan yang positif dan signifikan sebesar 0,388 antara motivasi belajar dengan prestasi belajar matematika.
\end{abstract}

Kata kunci : Motivasi Belajar, Prestasi Belajar, Matematika

\section{PENDAHULUAN}

Belajar adalah proses perubahan dalam diri manusia. Karena itu, bila suatu usaha belajar sudah selesai dan tidak terjadi perubahan didalam diri manusia, maka tidak dapat dikatakan bahwa telah terjadi proses belajar padanya (Syahrir, 2010). Terkadang satu proses tidak dapat mencapai hasil maksimal disebabkan karena ketiadaan kekuatan yang mendorong (motivasi).

Menurut (Djamarah, 2013) Belajar mengajar adalah suatu kegiatan yang bernilai edukatif. Nilai edukatif mewarnai intraksi yang terjadi antara guru dan anak didik. Karena dalam proses tersebut siswa tidak hanya sekedar menerima dan menyerap informasi yang disampaikan oleh guru, tetapi siswa dapat melibatkan diri dalam kegiatan pembelajaran yang harus dilakukan, agar hasil belajarnya lebih baik dan sempurna. Dari proses pembelajaran tersebut siswa dapat mengasilkan suatu perubahan yang bertahap dalam dirinya, baik dalam bidang pengetahuan, keterampilan dan sikap. Adanya perubahan tersebut dilihat dari prestasi belajar yang dihasilkan oleh siswa berdasarkan evaluasi yang diberikan oleh guru. Sebab hasil belajar itu akan optimal bila terdapat motivasi yang tepat. Karenanya, bila siswa mengalami kegagalan dalam belajar, hal ini bukan semata-mata kesalahan siswa, tetapi mungkin saja guru tidak berhasil dalam membangkitkan motivasi siswa.

Perhatian siswa terhadap stimulus belajar dapat diwujudkan melalui beberapa cara seperti penggunaan media pengajaran atau alatalat peraga, memberikan pertanyaan kepada siswa, membuat variasi belajar pada siswa, membuat variasi belajar pada siswa, melakukan pengulangan informasi yang berbeda dengan cara sebelumnya, memberikan stimulus lain pada siswa sehingga siswa tidak bosan. Dan ada beberapa motivasi yang digunakan guru terhadap bahan pelajaran agar siswa tidak merasa bosan, seperti: memberikan hadiah, pujian, gerakan tubuh, memberikan angka atau penilaian, membikan tugas dan hukuman. Motivasi yang kuat dalam diri siswa akan meningkatkan minat, kemauan dan semangat tinggi dalam belajar, karena antara motivasi dan semangat mempunyai hubungan yang erat. Sebagaimana yang dikatakan oleh Sardiman A.M dalam bukunya interaksi dan motivasi belajar mengajar bahwa : "Dalam kegiatan belajar, maka motivasi menimbulkan kegiatan 
belajar, menjamin kelangsungan dari kegiatan belajar, sehingga tujuan yang dikehendaki oleh subjek belajar itu dapat tercapai".

Menurut Gagne (Syahrir, 2010) belajar adalah kegiatan yang kompleks terdiri dari tiga komponen penting yaitu: kondisi eksternal, kondisi internal, dan hasil belajar. Sehingga belajar merupakan interaksi antara keadaan internal dan proses kognitif siswa dengan stimulus dan lingkungannya.

Motivasi berasal dari kata Inggris motivation yang berarti dorongan, pengalasan dan motivasi. Dalam kegiatan belajar mengajar dikenal dengan istilah motivasi belajar, yaitu motivasi yang diterapkan dalam kegiatan belajar. Motivasi belajar adalah keseluruhan daya penggerak psikis dalam diri siswa yang menimbulkan kegiatan belajar, menjamin kelangsungan belajar itu demi mencapai satu tujuan (Winskel, 1987). Motivasi belajar memegang peranan penting dalam memberikan gairah, semangat dan rasa senang dalam belajar sehingga yang mempunyai motivasi tinggi mempunyai energi yang banyak untuk melaksanakan kegiatan belajar. Siswa mempunyai motivasi tinggi sangat sedikit yang tertinggal belajarnya dan sangat sedikit pula kesalahan dalam belajarnya (Palardi, 1975).

Dalam diri siswa terdapat kekuatan mental yang menjadi penggerak belajar. Siswa belajar kerena didorong oleh kekuatan mentalnya. Kekuatan mental itu berupa keinginan, perhatian, kemauan, atau cita-cita. Kekuatan mental tersebut dapat tergolong rendah atau tinggi. Ada ahli psokologi pendidikan yang menyebut kekuatan mental yang mendorong terjadinya belajar tersebut sebagai motivasi belajar. Motivasi dipandang sebagai dorongan mental yang menggerakkan dan mengarahkan prilaku manusia, termasuk prilaku belajar. Dalam motivasi yang terkandung adanya keinginan yang mengaktifkan, menggerakkan, menyalurkan dan mengarahkan sikap dan prilaku individu belajar (Koeswara, 1989; Siagian, 1989; Schein, 1991; Biggs \& Telfer, 1987).

Pendapat lain juga mengatakan bahwa motivasi adalah " keadaan dalam diri seseorang yang mendorongnya untuk melakukan kegiatan untuk mencapai tujuan" (Soeharto dkk, 2003).Motivasi belajar adalah dorongan internal dan eksternal pada siswa-siswi yang sedang belajar untuk mengadakan perubahan tingkah laku, pada umumnya dengan memberikan indikator yang mendukung.
Schunk and Zimmerman (2009) berpendapat: "Among source of motivation the are: interests, self-efficacy, volition, task value, confidence in learning, outcome expentancy and future time perspective".

Pendapat diatas menjelaskan motivasi dapat dilihat dari: minat, kemandirian, kemauan, nilai ulangan, kepercayaan diri dalam belajar, orientasi pada hasil, dan pandangan terhadap masa depan

Gagne (1985) menyatakan bahwa prestasi belajar dibedakan menjadi 5 aspek yaitu: kemampuan intelaktual, strategi kognitif, informasi verbal, sikap dan keterampilan.Prestasi adalah kecakapan atau hasil kongkrit yang dapat dicapai pada saat periode tertentu. Prestasi dalam penelitian ini adalah hasil yang telah dicapai siswa dalam proses pembelajaran. Setiap kegiatan atau usaha yang dilakukan perlu diadakan penilaian untuk mengetahui sejauh mana tingkat keberhasilan yang dicapai sehingga dapat diketahui apakah tujuan tersebut tercapai atau belum. Tingkat keberhasilan yang dicapai dari suatu kegiatan disebut dengan istilah hasil atau prestasi. Kegiatan belajar menghasilkan perubahan pada siswa yang tampak pada tingkah laku atau prestasinnya. Prestasi belajar siswa ditentukan oleh kegiatan belajarnya.

\section{METODE PENELITIAN}

Adapun jenis penelitian digunakan adalah penelitian eksperimen dengan pendekatan kualitatif dan pendekatan kuantitatif. Desain yang digunakan yaitu Time Series Design. populasi dalam penelitian ini adalah Siswa Kelas VIII SMPN 1 Batukliang Utara berjumlah 105 orang. sampel dalam penelitian ini sebanyak 27 orang Siswa Kelas VIII A SMPN 1 Batukliang Utara .

Instrumen yang digunakan dalam penelitian ini adalah lembar angket dan lembar tes. bentuk angket yang digunakan adalah bentuk angket tertutup. Angket dalam penelitian ini digunakan untuk mengetahui motivasi belajar siswa dalam pembelajaran matematika sebelum dan setelah perlakuan. Untuk mendapatkan data prestasi belajar siswa, peneliti menggunakan data hasil tes yang didapatkan dari hasil pre-test dan posttest kelas eksperimen. Untuk mengetahui berapa besarnya Hubungan Antara Motivasi Belajar (Variable X) Dengan Prestasi Belajar (Variabel Y) Pada Siswa Kelas VIII SMPN 1 Batukliang Utara Tahun Pelajaran 2015/2016 maka digunakan persamaan regresi 
sederhana. Antara nilai motivasi dengan nilai prestasi dapat dihitung korelasinya.

\section{HASIL PENELITIAN DAN PEMBAHASAN}

Penelitian ini mendeskripsikan dan menguji hubungan dari variabel terikat, maka pada bagian ini akan disajikan deskripsi data dari masing-masing variabel berdasarkan data yang diperoleh dari lapangan.

Deskripsi Hasil Angket Motivasi Belajar

\section{Tabel 1. Data Motivasi Belajar}

\begin{tabular}{lc}
\hline \multicolumn{1}{c}{ Analisis } & Keterangan \\
\hline Skor Tertinggi & 100 \\
Skor Terendah & 66 \\
Rata-Rata & 91,74 \\
Kategori & Tinggi \\
\hline
\end{tabular}

Dari data di atas menunjukkan bahwa skor tertinggi 100 , serta skor terendah 66 , Ratarata skor angket 91,74, yang termasuk dalam kategori tinggi.

Adapun hasil pretest (tes awal) dan posttest (tes akhir) siswa untuk kelas eksperimen dapat dilihat pada tabel berikut:
Tabel 2. Data Hasil Pre-Test 1-4

\begin{tabular}{lc}
\hline \multicolumn{1}{c}{ Analisis } & Keterangan \\
\hline Skor Tertinggi & 80 \\
Skor Terendah & 20 \\
Rata- Rata & 58,52 \\
\hline
\end{tabular}

Dari data di atas menunjukkan bahwa skor tertinggi 80 , serta skor terendah 20, Rata-rata skor data hasi pretest prestasi 58,52.

Tabel 3. Data Hasil Post-Test 1-4

\begin{tabular}{lc}
\hline \multicolumn{1}{c}{ Analisis } & $\begin{array}{c}\text { Keterang } \\
\text { an }\end{array}$ \\
\hline Skor Tertinggi & 100 \\
Skor Terendah & 60 \\
Rata- Rata & 83,61 \\
\hline
\end{tabular}

Dari data di atas menunjukkan bahwa skor tertinggi 100 , serta skor terendah 60 , Rata-rata skor data hasi posttest prestasi 83,61.

Persamaan regresi

$$
\begin{gathered}
Y^{\prime}=a+b \mathrm{X} \\
=38,619+0,490(91,74) \\
=83,57
\end{gathered}
$$

\section{Membuat garis regresi}

Garis regresi dapat digambarkan persamaan yang telah ditemukan di atas adalah $\hat{Y}=38,619+0,490 \mathrm{X}$ atau $\hat{Y}=38,619+$ $0,490(91,74)=83,57$

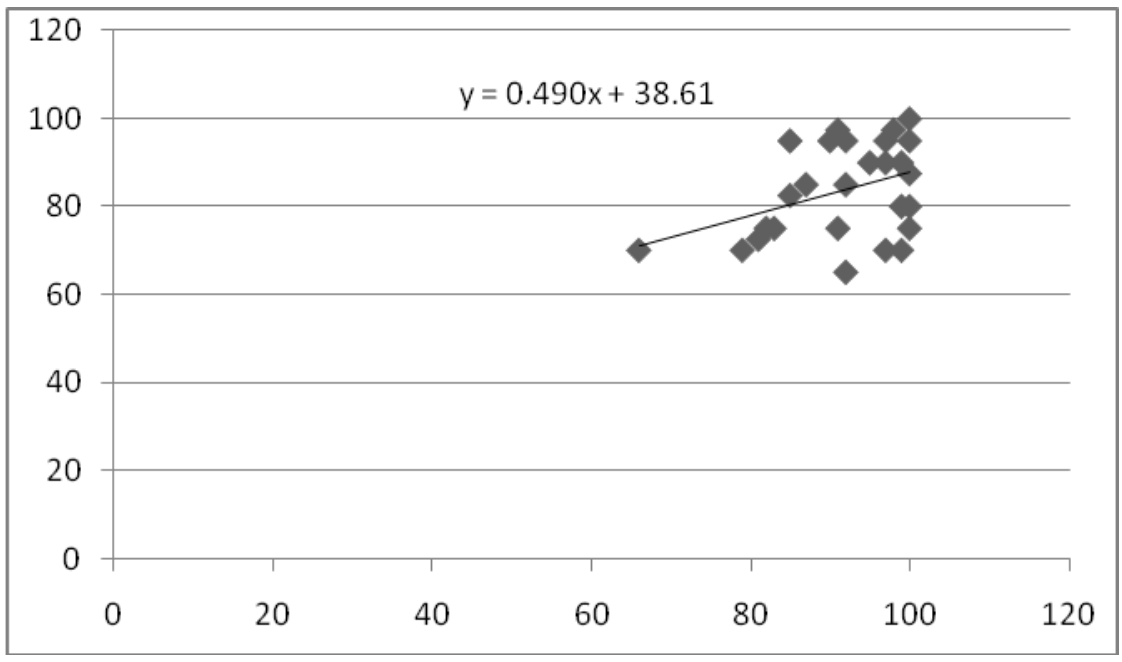

Gambar 1. Uji keberartian dan linearitas 
Tabel 4. Daftar Anava Untuk Regresi Linier

\begin{tabular}{lcccc}
\multicolumn{4}{c}{$\widehat{\boldsymbol{Y}}=38,619+0,490 \mathrm{X}$} \\
\hline $\begin{array}{l}\text { Sumber } \\
\text { variasi }\end{array}$ & Dk & JK & KT & F \\
\hline $\begin{array}{l}\text { Total } \\
\text { Koefisien }\end{array}$ & 27 & 191731,3 & & \\
(a) & 1 & 188752,08 & & \\
$\begin{array}{l}\text { Koefisien } \\
\text { (b|a) }\end{array}$ & 1 & 469,74 & 469,74 & \\
Sisa & 25 & 2509,74 & 100,38 & 4,679 \\
Tuna cocok & 10,5 & 1161,345 & 110,6 & \\
Galat & 14,5 & 1348,135 & 92,97 & 1,189 \\
\hline
\end{tabular}

Uji keberartian:

$H_{0}$ : Koefisien arah regresi tidak berarti $(b=0)$

$\mathrm{H}_{\mathrm{a}}$ : Koefisien itu regresi berarti $(b \neq 0)$

$$
\mathrm{F}=\frac{S_{\text {reg }}^{2}}{S_{\text {sis }}^{2}}(\mathrm{~F} \text { hitung })=4,679
$$

Untuk taraf kesalahan 5\%, $\mathrm{F}$ tabel $=4,24$

$\mathrm{F}$ hitung $>\mathrm{F}$ tabel baik untuk taraf $5 \%$.

Kesimpulannya koefisien itu berarti $(b \neq 0)$

Uji Linearitas :

$\mathrm{H}_{0}$ : regresi linier

$\mathrm{H}_{\mathrm{a}}$ : regresi non - linier

$\mathrm{F}=\frac{S_{T C}^{2}}{S_{G}^{2}}(\mathrm{~F}$ hitung $)=1,189$

Untuk taraf kesalahan $5 \%, \mathrm{~F}$ tabel $=2,60$

$\mathrm{F}$ hitung $>\mathrm{F}$ tabel baik untuk taraf kesalahan $5 \%$.

Kesimpulannya regresi linier, antara nilai motivasi dengan nilai prestasi dapat dihitung korelasinya.

$r=$ Harga $r$ tabel untuk taraf kesalahan $5 \%$ dengan $n=27$ diperoleh $r$ tabel $=$ 0,381 . Karena harga $r_{\text {hitung }}>r_{\text {tabel }} \quad(0,388>$ 0,381 ) maka dapat disimpulkan terdahan hubungan yang positif dan signifikan sebesar 0,388 antara motivasi belajar dengan prestasi belajar matematika.

Hasil penelitian ini menunjukkan ada hubungan antara motivasi belajar $(X)$ dengan prestasi belajar matematika siswa $(\mathrm{Y})$. Dari hasil analisis data di atas menunjukkan Persamaan Regresi Sederhana antara motivasi belajar dengan prestasi belajar matematika yang diperoleh nilai r-hitung 83,57 sedangkan besar angka pada tabel $r$ dengan taraf signifiikan 5\% dan $\mathrm{N}=27$ adalah 0,381 dengan demikian $r_{\text {hitung }}>r_{\text {tabel }}$ maka penelitian ini signifikan.

Dengan demikian ada hubungan antara motivasi belajar dengan prestasi belajar matematika pada siswa kelas VIII A SMPN 1 Batukliang Utara Tahun Pelajaran 2015/2016.

Motivasi belajar adalah keseluruhan daya penggerak psikis dalam diri siswa yang menimbulkan kegiatan belajar, menjamin kelangsungan belajar itu demi mencapai satu tujuan.,Dalam proses belajar mengajar motivasi sangat besar peranannya terhadap prestasi belajar. Karena dengan adannya motivasi dapat menumbuhkan minat belajar siswa. Bagi siswa yang memiliki motivasi yang kuat akan mempunyai keinginan untuk melaksanakan kegiatan belajar mengajar. Sehingga boleh jadi siswa yang memiliki intelegensi yang cukup tinggi menjadi gagal karena kekurangan motivasi, sebab hasil balajar itu akan optimal bila terdapat motivasi yang tepat. Karenanya, bila siswa mengalami kegagalan dalam belajar, hal ini bukanlah semata-mata kesalahan siswa, tetapi mungkin saja guru tidak berhasil dalam membangkitkan motivasi siswa.Dalam diri siswa terdapat kekuatan mental yang menjadi penggerak belajar. Siswa belajar kerena didorong oleh kekuatan mentalnya. Kekuatan mental itu berupa keinginan, perhatian, kemauan, atau cita-cita. Kekuatan mental tersebut dapat tergolong rendah atau tinggi. Ada ahli psokologi pendidikan yang menyebut kekuatan mental yang mendorong terjadinya belajar tersebut sebagai motivasi belajar. Motivasi dipandang sebagai dorongan mental yang menggerakkan dan mengarahkan prilaku manusia, termasuk prilaku belajar.

Perhatian siswa terhadap stimulus belajar dapat diwujudkan melalui beberapa cara seperti penggunaan media pengajaran atau alatalat peraga, memberikan pertanyaan kepada siswa, membuat variasi belajar pada siswa, melakukan pengulangan informasi yang berbeda dengan cara sebelumnya, memberikan stimulus belajar dalam bentuk lain sehingga siswa tidak bosan. Dan ada beberapa motivasi yang digunakan guru terhadap bahan pelajaran agar siswa tidak merasa bosan seperti : memberikan hadiah,pujian, gerakan tubuh, memberikan angka atau penilaian, memberikan tugas dan hukuman. Motivasi yang kuat dalam diri siswa akan meningkatkan minat, kemauan dan semangat yang tinggi dalam belajar, karena antara motivasi dan semangat belajar mempunyai hubungan yang erat. Sebagaimana yang dikatakan oleh sardiman " dalam kegiatan 
belajar, maka motivasi menimbulkan kegiatan belajar, menjamin kelangsungan dari kegiatan belajar, sehingga tujuan yang dikehendaki oleh subjek belajar itu dapat tercapai.Sehingga jelas bahwa semakin tinggi motivasi belajar siswa semakin tinggi pula prestasi belajar siswa.

\section{KESIMPULAN}

Berdasarkan hasil analisis yang dilakukan maka dapat ditarik kesimpulan yaitu ada hubungan antara motivasi belajar dengan prestasi belajar matematika pada siswa kelas VIII A SMPN 1 Batukliang Utara Tahun Pelajaran 2015/2016. Hal ini dibuktikan dengan hasil $r$ hitung sebesar 0,388 lebih besar dari $r$ tabel 0,381 dengan taraf signifikan $5 \%$ dan $n=$ 27.

\section{DAFTAR PUSTAKA}

Baharudin dan Wahyuni, 2009. Teori Belajar \& Pembelajaran: Jogjakarta : Ar-Ruzz Media.

Dimyanti dan Mudjiono. 2009. Belajar dan Pembelajaran. Jakarta: Rineka Cipta

Djamarah dan Zain,2013.Strategi Belajar Mengajar. Jakarta: Rineka Cipta

Hamalik oemar. 2001. Proses Belajar Mengajar. Jakarta : PT.Bumi Aksara

Sugiyono, 2011. Statistika Untuk Penelitian . Bandung :Alfabeta. 